\title{
The use of calcium phosphate cement in vertebroplasty of the base of odontoid process
}

\section{Zastosowanie cementu zawierajqcego fosforan wapnia do wertebroplastyki podstawy zęba kręgu obrotowego}

Krzysztof Zapałowicz', Maciej Woidyn', Krzysztof Włodzimierz Zieliński², Dorota Snopkowska-Wiaderna²

1Klinika Neurochirurgii i Chirurgii Nerwów Obwodowych Uniwersytetu Medycznego w Łodzi, Uniwersytecki Szpital Kliniczny im. WAM-CSW, tódź

2Zakład Patomorfologii i Cyłopatologii Klinicznej Uniwersytetu Medycznego w todzi, Uniwersytecki Szpital Kliniczny im. WAM-CSW, tódź

Neurologia i Neurochirurgia Polska 2013; 47, 6: 590-594

DOl: 10.5114/ninp.2013.39077

\begin{abstract}
The authors describe the use of bone cement containing calcium phosphate for vertebroplasty of the cavity in the base of odontoid process. A 23-year-old female patient was operated on by incision in lateral cervical area (anterior open access). After a blunt dissection, the working cannula (Kyphon) was introduced under fluoroscopic guidance through the $\mathrm{C} 2$ vertebral body to the cavity in the base of the odontoid process. Intraoperatively, biopsy of the lesion was taken and histopathological examination excluded the presence of neoplasm. The cavity, presumably haemangioma, was successfully filled with calcium phosphate bone cement KyphOs ${ }^{\mathrm{TM}}$ FS (Kyphon). The proper filling without paravertebral cement leak was confirmed by postoperative computed tomography (CT). The CT and magnetic resonance imaging performed 9 months after the procedure showed that cement was still present in the cavity. This is the first use of calcium phosphate cement to conduct the vertebroplasty of $\mathrm{C} 2$ vertebra.
\end{abstract}

Key words: vertebroplasty, minimally invasive surgery, fluoroscopic guidance, odontoid, vertebral haemangioma, injectable bone cement.

\section{Streszczenie}

Autorzy opisują zastosowanie cementu zawierającego nieorganiczne sole fosforanu wapnia do wertebroplastyki podstawy zęba kręgu C2. Zabieg wykonano u 23-letniej pacjentki. Przez kilkucentymetrowe nacięcie skóry w prawej okolicy bocznej szyi (otwarty dostęp przedni) do trzonu C2 wprowadzono w linii pośrodkowej kaniulę roboczą (Kyphon). Przez kaniulę pobrano materiał do badania histopatologicznego. Po wykluczeniu obecności komórek nowotworowych, do jamistej strefy na granicy trzonu i zęba kręgu obrotowego, określonej jako naczyniak, podano cement KyphOsTM FS (Kyphon). Pooperacyjna tomografia komputerowa (TK) potwierdziła całkowite wypełnienie jamy oraz kanału wytworzonego przez kaniulę; cement nie wydostał się poza kręg C2. Wykonane po 9 miesiącach TK i obrazowanie za pomocą rezonansu magnetycznego potwierdziły obecność cementu $\mathrm{w}$ miejscu podania. Jest to pierwsze zastosowanie cementu zawierającego fosforan wapnia do wertebroplastyki w obrębie kręgu C2.

Słowa kluczowe: wertebroplastyka, zabieg małoinwazyjny, nawigacja fluoroskopowa, kręg obrotowy, naczyniak trzonu.

Correspondence address: dr med. Krzysztof Zapałowicz, Klinika Neurochirurgii i Chirurgii Nerwów Obwodowych, Uniwersytet Medyczny w Łodzi, Uniwersytecki Szpital Kliniczny im. WAM-CSW, ul. Żeromskiego 113, 90-549 tódź, Polska, e-mail: krzysztofzapalowiczl@wp.pl Received: 3.03.2013; accepted: 27.05.2013 


\section{Introduction}

Vertebroplasty (VP) was first introduced in 1984 by Galibert et al. [1] who filled the haemangioma of $\mathrm{C} 2$ with polymethylmethacrylate (PMMA) through percutaneous anterolateral injection. Later on, the VP was developed and at present is widely applied to all segments of the spine $[1,2]$. Vertebroplasty of $\mathrm{C} 2$ is considered a challenging procedure putting at risk vital neighbouring structures, such as vessels, nerves and the spinal cord [2-6]. In order to introduce the needle into the $\mathrm{C} 2$ vertebra, the following routes were used: (a) transoral [2,7-9], (b) percutaneous anterolateral between the trachea with esophagus and carotid artery $[3,6,10]$ and (c) percutaneous posterolateral through the neck muscles and pedicle of $\mathrm{C} 2$ [4]. Some authors, however, advocated open access to C2. In 2008, Rhiew et al. [5] performed VP using an open minimally invasive anterior approach by small incision and blunt dissection of connective tissue between cervical vessels and trachea with esophagus. In 2010, Dorman described minimally invasive anterior approach for a one-stage $\mathrm{VP}$ of the dens and body of $\mathrm{C} 2$ [11]. Both aforementioned authors highlighted the following advantages of open access: minor risk of damaging and possibility of haemostasis under visual control $[5,11]$. In the present report, we describe the use of calcium phosphate cement (CPC) for $\mathrm{VP}$ of the base of odontoid through an open minimally invasive anterior approach.

\section{Case report}

A 23-year-old female patient was admitted with a diagnosed poorly trabeculated zone, located in the base of odontoid process (Fig. 1). Besides this, the patient did not declare any other traumas. Her general and neurological examination showed no abnormalities. The pathology was revealed two years before by computed tomography (CT) performed after neck trauma. The magnetic resonance imaging (MRI) at one-year follow-up did not show any enlargement suggestive for malignant or inflammatory lesion. It was advised to perform biopsy and VP in order to clarify the nature of abnormality and to reinforce the weakened base of the odontoid process. The risks and benefits of the procedure were reviewed with the patient, who gave the consent to proceed. The procedure was performed on $7^{\text {th }}$ July 2009 under general anaesthesia. The patient was placed in supine position. A longitudinal incision was made upon the anterior border of right sternocleidomastoid muscle at $\mathrm{C} 4-\mathrm{C} 5$ level. Blunt dissection of connective tissue between the carotid artery and the trachea with oesophagus was made in order to reach the C2-C3 disc (Fig. 2). Under fluoroscopic guidance, the $\mathrm{K}$-wire was positioned in the midline at the inferior portion of $\mathrm{C} 2$ and advanced through the $\mathrm{C} 2$ vertebral body to the cavity. Using $\mathrm{K}$-wire as a guide, the working cannula (Kyphon) was inserted into the cavity. We noted slow venous bleeding from the cannula. Probing with K-wire revealed that the cavity did not contain any tissue. Through the cannula, few biopsy specimens were obtained using the biopsy needle and pituitary punch. Immediate histopathologic examination demonstrated blood clots without evidence of neoplasmatic cells. Given this finding, the CPC KyphOs ${ }^{\mathrm{TM}} \mathrm{FS}$ (Kyphon) was delivered to the cavity under low pressure, using Bone Filler Device (Kyphon). The working cannula was then removed and its tunnel was also filled with cement. A total of $3.5 \mathrm{~mL}$ of cement was used. To guarantee the proper crystallization of the cement, the patient was kept supine on the surgical table until 30 minutes
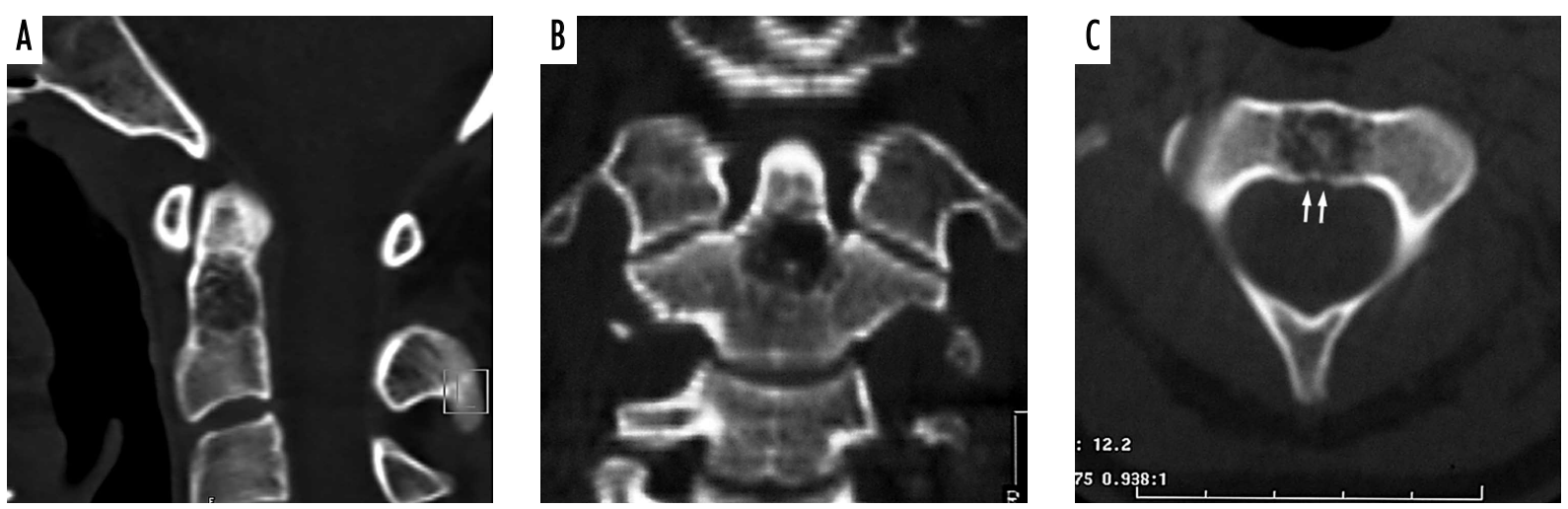

Fig. 1. Preoperative CT reconstructions: sagittal (A), coronal (B) and axial (C), showing cavity containing poor trabecular structure. Arrows indicate perforations of the posterior wall of the cavity 

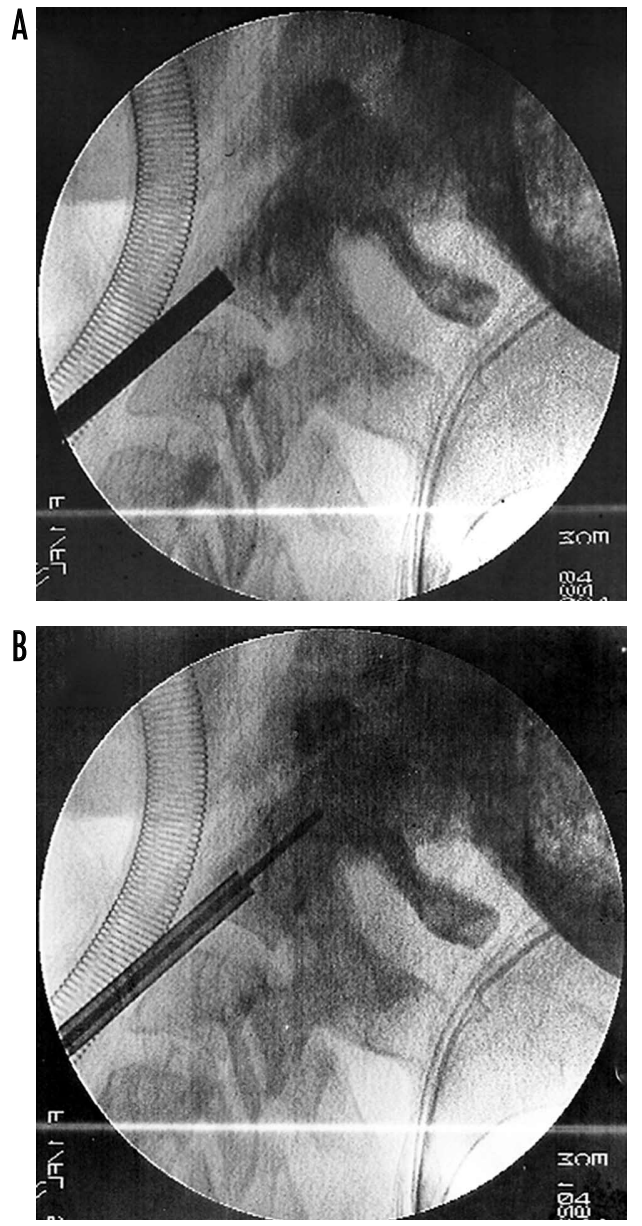

Fig. 2. Intraoperative fluoroscopic lateral view. (A) working cannula advanced in the C2 vertebral body. (B) bone biopsy needle introduced into the cavity

after the completion of VP, and continued a supine decubitus position for next 24 hours. The CT scan performed the following day showed satisfactory placement of cement in the cavity and in the body of $\mathrm{C} 2$, without any extravertebral leak (Fig. 3). The postoperative course was uneventful. Repeated CT and MRI carried out 9 months after procedure displayed presence of the cement in the cavity and in the body of C2 (Figs. 4 and 5).

\section{Discussion}

Up till now, VP of $\mathrm{C} 2$ was used for the treatment of following lesions: haemangiomas, neoplasms, fibrous dysplasia, inflammatory osteolysis, fracture due to aneurysmal bone cyst and noninflammatory lytic lesion [1-11]. All procedures were performed by means of PMMA [1-11]. Injectable PMMA remains the basic cement used for VP, however, it is not free from some drawbacks, such as: lack of osteointegrative capacity, excessive inherent stiffness, high polymerization temperature and potential risk of extravertebral leak or venous embolism [10, 12,13]. Anselmetti et al. [2] and Mont'Alverne et al. [3] in their series of vertebroplasties for neoplasmatic lesions of $\mathrm{C} 2$, found the rate of PMMA leaks as high as $26-58.3 \%$. Recently, the alternative filler materials calcium phosphate cements - were introduced and were used in cases of osteoporotic vertebral fractures as well as high-energy traumatic fractures in younger patients $[12,14]$. Unlike PMMA, they harden without thermal effect and offer possibility of osteointegration, which means that cement may be gradually resorbed and replaced by normal bone [12-14]. Bone cement KyphOsTM FS (Kyphon Inc.) is a CPC dedicated to balloon kyphoplasty. In order to guarantee the complete crystallization of CPC, the patient must not be moved from the procedure table until $30 \mathrm{~min}$ after final cement delivery and afterwards should remain on bed rest for the next 24 hours [12]. We treated the pathological cavity being aware that its repeated preoperative imaging did not
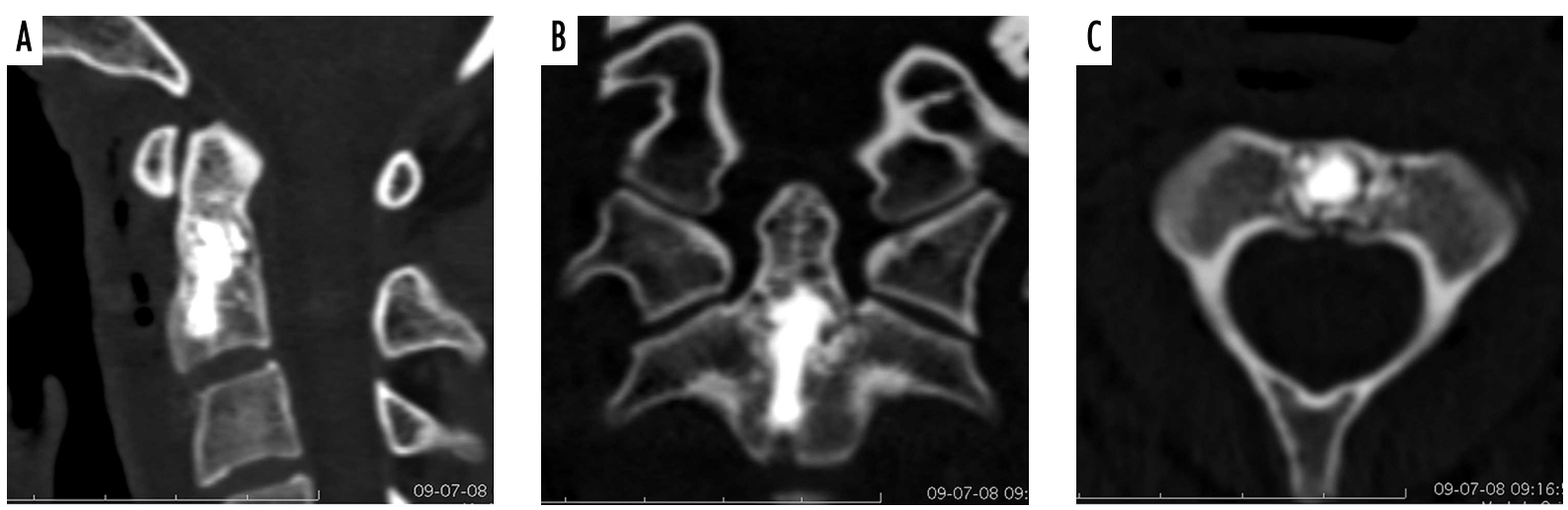

Fig. 3. CT performed on the first postoperative day: sagittal (A), coronal (B) and axial (C) reconstructions, showing cavity and tunnel taped by working cannula filled with CPC, without any extravertebral leak 

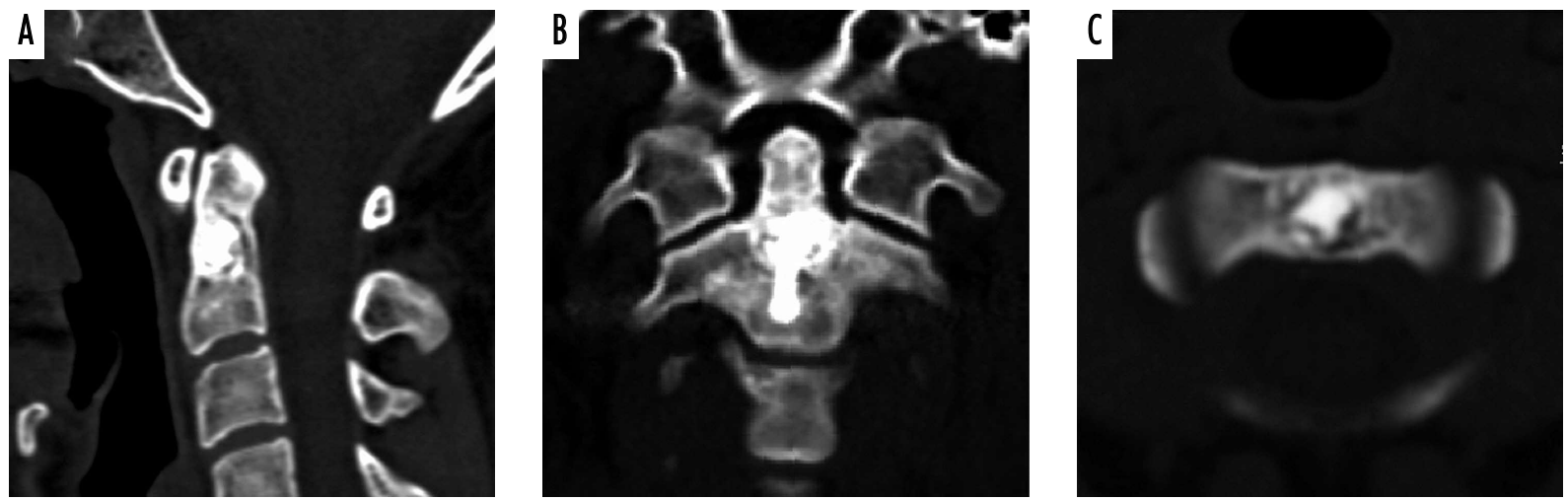

Fig. 4. CT performed 9 months after vertebroplasty: sagittal (A), coronal (B) and axial (C) reconstructions, showing cement mass present in the cavity
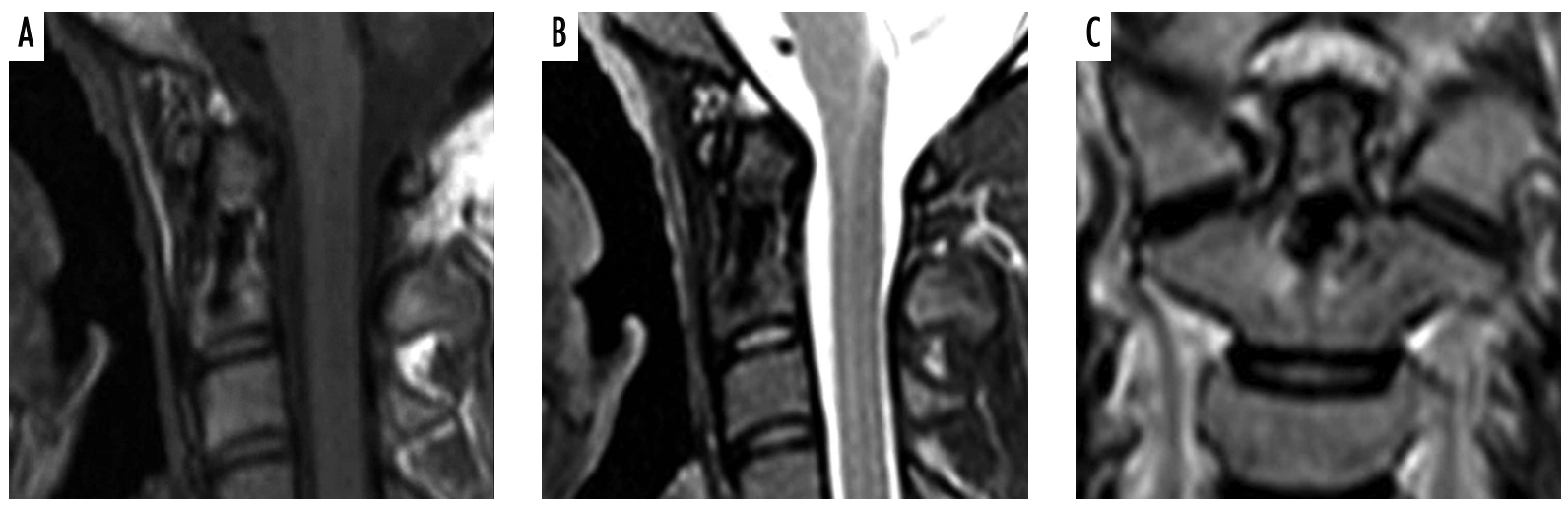

Fig. 5. Non-enhanced MRI obtained 9 months after vertebroplasty, showing cement mass in the dens and vertebral body of C2. (A) T1-weighted sagittal,

(B) T2-weighted sagittal and (C) T2-weighted coronal images

show any enlargement suggestive for malignant or inflammatory lesion. Computed tomography revealed absence of normal spongious bone in the cavity, nonetheless few bony trabeculae were present. For this reason, the odontoid process was linked with the body of $\mathrm{C} 2$ vertebra by the layer of cortical bone only. As a consequence, base of the odontoid process of this patient was weakened and might have been prone to fracture. Concerning the choice of operative method, we ruled out transoral VP taking into account the risk of fracture or invagination of thin cortical bone during direct piercing. We chose the open access described by Rhiew et al., more invasive than percutaneous or transoral ones, but allowing safe introduction of cannula to the target through $\mathrm{C} 2$ vertebral body. To avoid potential deleterious effects of PMMA (high temperature of polymerization, excessive stiffness) on thin cortical bone surrounding the cavity, we decided to use CPC. We took into account the young age of the patient as well as the following advantages of the latter cement: hardening without any thermal effect, ability to be osteoconductive and biodegradable. Had the biopsy revealed neoplasmatic cells, PMMA would have been used for VP and perhaps additional open surgery would have been indicated. We defined treated lesion as vertebral haemangioma, provided the radiologic imaging (presence of few thick bone trabeculae in the cavity), intraoperative findings (space filled with venous blood), and histopathological finding (lack of malignant cells).

To the best of our knowledge, this is the only known case of $\mathrm{VP}$ of the $\mathrm{C} 2$ with $\mathrm{CPC}$. One of the qualities of this paper is long-term evaluation (9 months later) of the cement by the means of CT and MRI.

\section{Conclusions}

Minimally invasive anterolateral access and placement of the working cannula through the $\mathrm{C} 2$ vertebral body has proven to be effective and safe for vertebroplasty of the base of odontoid process. In this case, calcium phosphate cement has been established as an effective filling material. 


\section{Disclosure}

Authors report no conflict of interest.

\section{References}

1. Mathis J.M., Belkoff S.M., Deramond H. History and early development of percutaneous vertebroplasty. In: Mathis J.M., Deramond H., Belkoff S.M. [eds.]. Percutaneous vertebroplasty and kyphoplasty. $2^{\text {nd }}$ ed. Springer Science + Bussiness Media, Inc., New York 2006, pp. 3-7.

2. Anselmetti G.C., Manca A., Montemurro F., et al. Vertebroplasty using transoral approach in painful malignant involvement of the second cervical vertebra (C2): a single-institution series of 25 patients. Pain Physician 2012; 15: 35-42.

3. Mont'Alverne F., Vallée J.N., Cormier E., et al. Percutaneous vertebroplasty for metastatic involvement of the axis. AJNR Am $J$ Neuroradiol 2005; 26: 1641-1645.

4. Sun H.Y., Lee J.W., Kim K.J., et al. Percutaneous intervention of the $\mathrm{C} 2$ vertebral body using a CT-guided posterolateral approach. AJR Am J Roentgenol 2009; 193: 1703-1705.

5. Rhiew R., Manjila S., DeZure A., et al. Minimally invasive anterior vertebroplasty for C-2 metastatic lesions. Neurosurg Focus 2008; 25 (2): E4.

6. Rodriguez-Catarino M., Blimark C., Willén J., et al. Percutaneos vertebroplasty at $\mathrm{C} 2$ : case report of a patient with multiple myeloma and a literature review. Eur Spine J 2007; 16 (Suppl 3): S242-S249.

7. Reddy A.S., Hochman M., Loh S., et al. CT guided direct transoral approach to $\mathrm{C} 2$ for percutaneous vertebroplasty. Pain Physician 2005; 8: 235-238.

8. Gailloud P., Martin J.B., Olivi A., et al. Transoral vertebroplasty for a fractured C2 aneurysmal bone cyst. $J$ Vasc Interv Radiol 2002; 13: 340-341.

9. Tong F.C., Cloft H.J., Joseph G.J., et al. Transoral approach to cervical vertebroplasty for multiple myeloma. AJR Am J Roentgenol 2000; 175: 1322-1324.

10. Cotten A., Boutry N., Cortet B. Percutaneous vertebroplasty: state of the art. Radiographics 1998; 18: 311-320.

11. Dorman J.K. Vertebroplasty of the $\mathrm{C} 2$ vertebral body and dens using an anterior cervical approach: technical case report. Neurosurgery 2010; 67: E1143-E1146.

12. Gioia G., Mandelli D., Gogue R. Treatment of typical amyelic somatic fractures with kyphoplasty and calcium phosphate cement a critical analysis. Eur Spine J 2012; 21 (Suppl 1): S108-S111.

13. Lieberman I.H., Togawa D., Kayanja M.M. Vertebroplasty and kyphoplasty: filler materials. Spine J 2005; 5: 305S-316S.

14. Nakano M., Hirano N., Ishihara H., et al. Calcium phosphate cement-based vertebroplasty compared with conservative treatment for osteoporotic compression fractures: a matched casecontrol study. J Neurosurg Spine 2006; 4: 110-117. 